\title{
Profil Komunikasi Interpersonal Peserta Didik dan Implikasi pada Program Bimbingan Pribadi Sosial
}

\author{
Yerika Arum Pertiwi \\ Program Studi Bimbingan dan Konseling, Fakultas Keguruan dan Ilmu Pendidikan, \\ Universitas Sultan Ageng Tirtayasa \\ yerikarum21@gmail.com
}

\begin{abstract}
Abstrak
Penelitian dilakukan dengan tujuan untuk mengetahui serta mendeskripsikan gambaran kemampuan komunikasi interpersonal peserta didik, serta mengetahui program bimbingan pribadi sosial yang dibuat berdasarkan gambaran kemampuan komunikasi interpersonal peserta didik kelas VII SMP Negeri 2 Kota Serang. Teknik pengambilan data pada penelitian menggunakan purposive sampling yang ditentukan berdasarkan perilaku dalam indikator komunikasi interpersonal seperti sulit menyesuaikan diri dengan lingkungan sekitar, mengabaikan pendapat orang lain, sulit berkomunikasi dengan orang lain, serta sulit menyampaikan ide atau gagasan di depan umum. Hasil analisis kuesioner komunikasi interpersonal pada peserta didik kelas VII SMP Negeri 2 Kota Serang terdapat sebesar 36,03\% dengan kategori rendah, $47,7 \%$ dengan kategori sedang, dan $16,27 \%$ kategori tinggi yang selanjutnya dibuat rancangan program bimbingan pribadi sosial agar dapat meningkatkan kemampuan komunikasi interpersonal peserta didik.
\end{abstract}

Kata Kunci: Komunikasi Interpersonal; Purposive Sampling; Program Bimbingan Pribadi Sosial.

\begin{abstract}
The research was carried out with the aim of knowing and describing the description of student interpersonal communication skills, as well as knowing the social personal guidance program which was made based on the description of the interpersonal communication skills of students in grade VII SMP Negeri Kota Serang. Data collection techniques in the study used purposive sampling which was determined based on behaviour in interpersonal communication indicators such as difficulty adapting to the surrounding environment, ignoring other people's opinions, difficulty communicating with others, and difficulty conveying ideas in public. The result of the analysis of the interpersonal communication questionnaire of SMP Negeri 2 Kota Serang students were $36,03 \%$ with the low category, $47,7 \%$ in the mediu category, and 16,27\% in the high category which was then made to design a social personal guidance program so that it could improve students interpersonal communication skills.
\end{abstract}


$124 \mid$ Pertiwi - Profil Komunikasi Interpersonal ...

Keywords: Interpersonal Communication; Purposive Sampling; Social Personal Guidance Program

\section{PENDAHULUAN}

Pembelajaran menurut Hamalik (2006, hlm. 12) diartikan sebagai proses terjadinya interaksi antara pelajar dan pengajar dalam upaya mencapai tujuan pembelajaran, yang berlangsung dalam suatu lokasi tertentu dalam jangka satuan waktu tertentu. Pada proses pembelajaran, interaksi antara pelajar merupakan hal yang perlu diperhatikan karena peserta didik dapat berpartisipasi dalam kegiatan belajar mengajar, bersosialisasi dengan teman sebayanya, serta menumbuhkan rasa percaya diri terhadap setiap individu peserta didik. Proses saat melakukan interaksi antara pelajar dengan pelajar, maupun pelajar dengan pengajar disebut komunikasi. Scheidel (Mulyana, 2016, hlm. 4) mengemukakan bahwa berkomunikasi terutama untuk menyatakan dan mendukung identitas diri untuk membangun kontak sosial dengan orang di sekitar, dan untuk mempengaruhi orang lain untuk merasa, berpikir, atau berperilaku seperti yang kita inginkan.

Pada kenyataannya, ada banyak hambatan saat melakukan komunikasi interpersonal. Hambatan dalam komunikasi interpersonal dapat terjadi karena setiap peserta didik memiliki pola pikir yang berbeda dalam menanggapi suatu kejadian atau peristiwa. Hambatan komunikasi interpersonal yang kerap terjadi di sekolah adalah peserta didik takut untuk mengkomunikasikan mengenai permasalahan yang sedang dihadapinya kepada teman sebayanya sehingga peserta didik sering merasa sendiri. Disisi lain, ada pula peserta didik yang belum memiliki keberanian untuk menanggapi atau membantu permasalahan yang sedang dihadapi oleh temannya.

Permasalahan komunikasi interpersonal yang peneliti angkat yaitu pada SMP Negeri 2 Kota Serang yang telah dibuktikan dari hasil wawancara yang dilakukan dengan guru BK kelas VII, yang menurut penuturannya dan pengalamannya selama mengajar, peserta didik SMP Negeri 2 Kota Serang memiliki permasalahan dalam komunikasi interpersonal seperti masih sering dipergunakannya kata-kata kasar dalam berkomunikasi sehari-hari. Selain itu, permasalahan komunikasi interpersonal lain yang ditemukan adalah kurangnya sikap keterbukaan pada peserta didik. Sebagai contoh, tidak dapat menyampaikan pendapat atau informasi kepada teman sebayanya atau saat berada dalam situasi belajar. Beberapa peserta didik menganggap bahwa jika memberikan pendapat atau informasi dalam suasana belajar hanya akan menjadikan dirinya sebagai orang yang mencari perhatian kepada guru mata pelajaran yang bersangkutan.

Permasalahan lain yang diungkapkan oleh guru BK pada saat wawancara adalah kesalahan persepsi peserta didik pada salah satu aspek komunikasi interpersonal yaitu sikap mendukung. Pada suatu kelas, terdapat peserta didik yang mendukung temannya untuk dapat berpendapat atau memberikan jawaban ketika ditanya oleh guru mata pelajaran dengan cara berteriak menyemangati dengan memanggil nama julukan temannya dengan sebutan yang kurang pantas. Tujuan dari sikap memanggil nama julukan teman adalah untuk mendukung 
temannya, tetapi yang disemangati menjadi malu dan enggan untuk menjawab pertanyaan guru.

Komunikasi interpersonal menjadi penting karena merupakan hal yang dianggap efektif dalam upaya mengubah sikap, perilaku, atau pendapat seseorang berdasarkan sifat dari komunikasi interpersonal yaitu dialogis berupa percakapan antara dua orang atau lebih. Peserta didik yang memiliki kekurangan dalam kemampuan atau keterampilan berkomunikasi interpersonal menurut Zuhara (2015, hlm. 87) cenderung menunjukkan perilaku yang negatif seperti tidak diterima oleh lingkungannya, ditolak, dan dikucilkan, sehingga siswa semakin kesulitan dalam melakukan interaksi sosial yang lebih baik. Dampak lain akibat komunikasi interpersonal yang tidak efektif adalah memicu perselisihan, menimbulkan kesalahpahaman, mudah melakukan labelling (penilaian buruk kepada orang lain) menimbulkan kesalahan informasi, dan merenggangkan hubungan sosial.

Fungsi dari komunikasi interpersonal antara lain sebagai sarana bagi peserta didik untuk dapat memperluas garis pertemanan, memahami diri sendiri dan orang lain, serta melatih kemampuan berbicara atau berpendapat peserta didik. Langkah yang dapat dilakukan pihak sekolah, khususnya guru bimbingan dan konseling terhadap permasalahan yang telah dijabarkan adalah dengan memberikan bantuan layanan yang tepat untuk meningkatkan kemampuan komunikasi interpersonal peserta didik. Bimbingan dan konseling memiliki beberapa bidang, salah satunya adalah pribadi sosial yang menurut Ahmadi (Khalilah, 2017, hlm. 49) bimbingan pribadi sosial dapat diberikan kepada individu agar dapat menghadapi serta memecahkan permasalahan pribadi sosialnya secara mandiri.

Lebih lanjut lagi, Gordon (Yulianty, 2015, hlm. 34) mengemukakan bahwa bimbingan pribadi sosial adalah proses bantuan kepada individu dalam memahami kelebihan dan kekurangannya. Bimbingan pribadi sosial diarahkan agar individu dapat memahami dan menyelesaikan masalah pribadinya sehingga memiliki kepribadian yang baik sehingga individu memperoleh pemahaman dirinya dalam mengidentifikasi dan mengekspresikan perasaan diri. Berdasarkan penjabaran latar belakang yang telah diuraikan, maka penelitian diharapkan dapat meningkatkan kemampuan komunikasi interpersonal peserta didik khususnya peserta didik kelas VII SMPN 2 Kota Serang.

\section{METODE PENELITIAN}

Metode yang akan digunakan pada penelitian adalah metode kuantitatif. Menurut Indrawan dan Yaniawati (2014, hlm. 141) merupakan upaya peneliti untuk mengumpulkan data yang bersifat angka, atau juga bukan angka namun bisa dikuantifikasikan. Penelitian yang dilakukan menggunakan teknik deskriptif. Penelitian dengan teknik deskriptif menurut Soebardhy, et.al (2019, hlm. 83) dirancang untuk memperoleh informasi tentang status gejala pada penelitian yang dilakukan serta diarahkan untuk menerapkan sifat seuatu situasi pada saat penyelidikan dilakukan. Deskriptif bertujuan untuk membuat sebuah gambaran mengenai situasi yang aktual dan akurat dari fakta dan sifat populasi atau daerah tertentu. 


\section{Populasi dan Sampel}

Populasi menurut Yusuf (2014, hlm. 144) yaitu sebuah hal yang esensial serta perlu mendapat perhatian dengan seksama jika peneliti ingin menyimpulkan hasil yang dapat dipercaya serta efektif untuk daerah atau objek penelitiannya. Peneliti menentukan populasi yang akan diteliti adalah peserta didik kelas VII SMP Negeri 2 Kota Serang tahun ajaran 2019 - 2020. Berikut merupakan data kelas VII SMP Negeri 2 Kota Serang:

\begin{tabular}{lrl}
\hline No. & Kelas & Jumlah Peserta Didik \\
\hline 1. & VII C & 37 \\
2. & VII E & 38 \\
3. & VII F & 36 \\
\hline Jumlah & $\mathbf{1 1 1}$
\end{tabular}

Terdapat dua sampel atau teknik sampling menurut Sugiyono (2016, hlm. 82), salah satunya nonprobability sampling. Nonprobability sampling merupakan teknik pengambilan sampel yang tidak memberikan peluang atau kesempatan yang sama bagi setiap unsur atau anggota populasi yang kemudian dipilih dijadikan sampel. Teknik sampel pada nonprobability sampling diantaranya sampling sistematis, kuota, aksidental, purposive, jenuh, dan snowball. Penelitian menggunakan purposive sampling dan Sugiyono (2016, hlm. 85) menyatakan bahwa purposive merupakan teknik pengambilan sampel sumber data dengan pertimbangan tertentu.

Rasionalisasi penggunaan teknik purposive sampling adalah tidak semua sampel memiliki kriteria yang sesuai dengan variabel yang akan diteliti, yaitu kemampuan komunikasi interpersonal yang rendah. Selain itu, penggunaak teknik purposive sampling dikuatkan oleh penuturan guru bimbingan dan konseling kelas VII yang menurut pengalaman mengajarnya terdapat tiga kelas yang memiliki kemampuan interpersonal yang rendah. Adapun kriteria dalam penentuan sampel penelitian sebagai berikut.

a. Konsep diri peserta didik dengan ciri sulit menyesuaikan diri dengan lingkungan sekitar.

b. Mengabaikan pendapat orang lain.

c. Sulit untuk berkomunikasi dengan orang lain.

d. Tidak ingin menyampaikan pendapat, gagasan atau ide di depan umum.

e. Sulit untuk menyesuaikan diri dengan lingkungan sekitar dan tidak suka mendengarkan pendapat orang lain.

\section{Definisi Operasional}

Definisi operasional dalam penelitian ini adalah sebagai berikut.

1. Komunikasi Interpersonal

Komunikasi interpersonal menurut Berger, Dainton \& Stafford (West \& Turner, 2017, hlm. 36) merujuk kepada komunikasi yang terjadi secara langsung antara dua orang. 
Penelitian yang dilakukan di SMPN 2 Kota Serang bertujuan untuk menemukan peserta didik yang memiliki kemampuan komunikasi interpersonal rendah dengan pemberian instrumen berdasarkan teori De Vito mengenai aspek yang dapat memengaruhi efektifnya suatu komunikasi interpersonal, yaitu keterbukaan, empati, dukungan, kepositifan, dan kesederajatan/kesetaraan.

2. Program Bimbingan dan Konseling

Program bimbingan dan konseling akan difokuskan kepada layanan bimbingan pribadi sosial yang terdiri dari serangkaian layanan dan akan diberikan oleh guru bimbingan dan konseling dengan tujuan meningkatkan komunikasi interpersonal peserta didik kelas VII SMP Negeri 2 Kota Serang tahun ajaran 2019 - 2020.

\section{HASIL DAN PEMBAHASAN}

Komunikasi interpersonal menurut Berger, Dainton \& Stafford (West \& Turner, 2017, hlm. 36) merujuk kepada komunikasi yang terjadi secara langsung antara dua orang. Konteks interpersonal banyak membahas tentang bagaimana mempertahankan suatu hubungan dimulai, bagaimana mempertahankan suatu hubungan, dan keretakan suatu hubungan. Penelitian dilaksanakan dengan cara pemberian kuesioner komunikasi interpersonal dengan tujuan untuk mendapatkan gambaran tingkat kemampuan komunikasi interpersonal kepada tiga kelas di kelas VII SMP Negeri 2 Kota Serang. Hasil kuesioner dibagi kedalam tiga kategori yaitu rendah, sedang, dan tinggi. Berdasarkan penghitungan yang telah dilakukan, maka berikut adalah hasil analisis tingkat komunikasi interpersonal peserta didik kelas VII SMP Negeri 2 Kota Serang:

\begin{tabular}{llll}
\hline Kategori & $\begin{array}{c}\text { Rentang } \\
\text { Nilai }\end{array}$ & Responden & Persentase \\
\hline Rendah & $\mathrm{x}<11$ & 40 & $36,03 \%$ \\
Sedang & $11 \leq \mathrm{x} \leq 32$ & 53 & $47,7 \%$ \\
Tinggi & $\mathrm{x}>32$ & 18 & $16,27 \%$ \\
Jumlah & & $\mathbf{1 1 1}$ & $\mathbf{1 0 0 \%}$ \\
\hline
\end{tabular}

Tabel diatas menunjukkan kemampuan komunikasi interpersonal peserta didik kelas VII SMP Negeri 2 Kota Serang dengan jumlah responden 111 peserta didik. Kemampuan komunikasi interpersonal dibagi ke dalam tiga kategori dengan rincian 36,03\% atau sebanyak 40 peserta didik dengan kategori rendah, 47,7\% atau 53 peserta didik dengan kategori sedang, serta $16,27 \%$ atau 18 peserta didik dengan kategori tinggi.

\section{Indikator Keterbukaan}

Komunikasi interpersonal peserta didik kelas VII SMP Negeri 2 Kota Serang dengan jumlah responden 111 peserta didik. Kemampuan komunikasi interpersonal tiap indikator dibagi ke dalam tiga kategori dengan rincian sebanyak 16,2\% atau 18 peserta 
didik dengan kategori rendah. Peserta didik pada kategori rendah memiliki permasalahan yaitu kesulitan dalam memposisikan diri sebagai orang lain pada situasi tertentu, sehingga tidak dapat merasakan perasaan orang lain. Selanjutnya sebanyak $78,3 \%$ atau 87 peserta didik dengan kategori sedang memiliki permasalahan yaitu tidak memerlukan pendapat orang lain, serta tidak dapat mengingatkan orang lain yang melakukan kesalahan tanpa membuat orang lain tersinggung, serta 5,4\% atau 6 peserta didik dengan kategori tinggi telah memiliki sikap terbuka dalam menyampaikan pendapat, serta menerima pendapat orang lain.

Peserta didik yang memiliki keterampilan keterbukaan yang tinggi hanya sebanyak 6 orang dari seluruh responden yang menandakan bahwa peserta didik kelas VII SMP Negeri 2 Kota Serang memerlukan adanya pemberian layanan dengan tema keterampilan keterbukaan. Pemberian layanan akan difokuskan kepada satu sub indikator paling rendah berdasarkan hasil analisis kuesioner, yaitu peserta didik belum memiliki sikap terbuka dalam mengungkapkan pendapat, saran, dan informasi lainnya. Layanan bimbingan pribadi sosial yang diberikan untuk meningkatkan keterampilan keterbukaan dalam menyampaikan pendapat salah satunya dengan menggunakan layanan bimbingan kelompok.

\section{Indikator Empati}

Hurlock (Asih \& Pratiwi, 2010, hlm. 34) menjelaskan bahwa arti dari empati adalah kemampuan yang seseorang miliki untuk dapat mengerti perasaan dan emosi orang lain serta memposisikan diri sendiri sebagai orang lain, serta empati dapat menggerakkan hati seseorang untuk membantu orang lain. Selanjutnya Goleman (Sari, et al., 2003, hlm. 83) mengungkapkan bahwa syarat untuk dapat melakukan empati adalah adanya kesadaran diri, serta dapat mengenali sinyal perasaan yang tersembunyi dalam reaksi tubuh sendiri, yang berarti seseorang dapat berempati jika dapat mengenali dirinya sendiri. Hasil analisis kuesioner komunikasi interpersonal peserta didik kelas VII SMP Negeri2 Kota Serang menunjukkan sebanyak 13,5\% atau 15 peserta didik dengan kategori rendah dengan permasalahan yaitu kesulitan dalam memposisikan diri sebagai orang lain pada situasi tertentu, sehingga tidak dapat merasakan perasaan orang lain. Pada kategori sedang sebesar $64 \%$ atau 71 peserta didik memiliki kesulitan dalam mengungkapkan rasa sayang atau berterimakasih kepada orang lain., serta 22,5\% atau 25 peserta didik dengan kategori tinggi sudah dapat menghibur teman yang sedang bersedih, serta dengan penuh ikhlas menolong teman yang mengalami kesulitan.

Keterampilan empati peserta didik kelas VII SMP Negeri 2 Kota Serang sudah cukup baik, tetapi masih perlu diberikan layanan agar dapat meningkatkan keterampilan empati pada peserta didik dengan kategori rendah. Salah satu layanan bimbingan pribadi sosial yang akan diberikan adalah melalui bimbingan kelompok dengan metode experiental learning. Experiental learning dikemukakan oleh Kolb (Wulandari, et al., 2012, hlm. 42) yakni merupakan sebuah pengetahuan yang didapatkan berdasarkan perubahan pengalaman seseorang. Lebih lanjut, menjelaskan dalam penelitiannya bahwa empati dapat ditingkatkan dengan experiental learning yang dapat menciptakan suasana 
menyenangkan dan kondusif pada pelaksanaannya. Hasil dari pemberian layanan dengan metode experiental learning diantaranya peserta didik dapat memahami kekurangan yang dimiliki oleh orang lain, dapat terbuka atas perasaannya kepada peserta didik lainnya, dapat percaya kepada orang lain tanpa adanya kecurigaan yang berarti, serta dapat membagikan pengalaman yang telah dilaluinya tanpa perasaan malu.

\section{Indikator Dukungan}

Kriteria sebuah komunikasi interpersonal dapat dikatakan efektif menurut De Vito salah satunya adanya aspek dukungan (supportiveness). Menurut Gibb (Rakhmat, 2005, hlm. 134) terdapat enam perilaku yang menggambarkan dukungan, yang pertama adanya deskripsi. Deskripsi merupakan suatu cara seseorang untuk menyampaikan persepsi dan perasaan tanpa menilai. Orang lain akan tetap merasa dihargai meskipun saat sedang dievaluasi cara pikir, gagasan, ataupun idenya. Perolehan hasil kuesioner pada indikator dukungan yakni sebesar $29,8 \%$ atau 33 peserta didik dengan kategori rendah dengan permasalahan peserta didik menertawakan teman yang dihukum karena sering terambat ke sekolah, serta acuh pada keadaan sekitar. Pada kategori sedang terdapat sebesar 50,4\% atau 56 peserta didik memiliki permasalahan peserta didik terletak pada tidak memberikan semangat kepada teman yang sedang mengikuti perlombaan atau situasi kompetitif lainnya, serta 19,8\% atau 22 peserta didik dengan kategori tinggi telah mampu memuji pekerjaan yang telah dikerjakan orang lain, serta dapat menawarkan bantuan kepada orang lain.

Berdasarkan hasil analisis kuesioner, peserta didik sangat memerlukan layanan untuk meningkatkan keterampilan dukungan. Layanan akan difokuskan kepada satu sub indikator paling rendah berdasarkan hasil analisis kuesioner, yaitu peserta didik belum memiliki kesediaan untuk memberikan dukungan kepada orang lain. Layanan bimbingan pribadi sosial yang diberikan untuk meningkatkan keterampilan keterbukaan dalam menyampaikan pendapat salah satunya dengan menggunakan layanan bimbingan klasikal dan bimbingan kelompok.

Bimbingan klasikal menurut Fatimah (2017, hlm. 28) merupakan layanan bantuan yang diberikan kepada seluruh peserta didik yang berada di dalam kelas. Bimbingan klasikal menunjukkan bahwa pada pelaksanaannya terdapat sebuah proses bimbingan yang disusun secara sistematis dan selanjutnya akan diberikan kepada peserta didik dengan terjadwal. Kegiatan yang ada pada bimbingan klasikal yaitu pemberian informasi yang diberikan oleh seseorang yang ahli di bidangnya kepada peserta didik secara langsung dengan tujuan agar peserta didik dapat mencapai tahap perkembangannya serta mengarahkan hidupnya. Layanan bimbingan klasikal dapat berupa metode ceramah, ataupun pengajaran bimbingan. Pemberian bimbingan kasikal akanditujukan kepada peserta didik yang memiliki keterampilan dukungan dengan kategori sedang. Materi bimbingan klasikal pada sub indikator dukungan akan merujuk kepada pengembangan keterampilan dukungan sosial, tujuan dari dukungan sosial, hingga dampak yang terjadi jika tidak adanya dukungan sosial dari orang-orang di sekitar.

Sementara itu untuk peserta didik yang memiliki keterampilan dukungan dengan kategori rendah akan diberikan layanan bimbingan kelompok dengan menggunakan 
metode atau teknik permainan (game). Teknik game pada bimbingan kelompok memiliki fungsi menurut Maulana, Wibowo dan Tadjri (2014, hlm. 92) adalah untuk meningkatkan keterampilan peserta didik dengan lingkungannya dalam bersosialisasi, serta ekspresi dan emosi. Pemilihan teknik permainan diharapkan dapat meningkatkan keterampilan dukungan peserta didik sehingga dapat melakukan komunikasi interpersonal secara efektif.

\section{Indikator Kepositifan}

Kepositifan atau rasa positif menurut Narti (2019, hlm. 330) adalah kemampuan seseorang untuk dapat melakukan sesuatu atas dasar pemikiran serta penilaian yang baik, mampu menerima diri sendiri sebagai seseorang yang berguna untuk orang lain, yakin bahwa dirinya dapat mengatasi sebuah permasalahan, serta mampu menyadari keadaan sekitarnya. Rasa positif pada komunikasi merupakan hal yang sangat penting karena dengan adanya pemikiran positif kepada orang lain, maka dapat menciptakan suasana yang menyenangkan sehingga proses interaksi tidak akan terputus.

Perolehan hasil kuesioner pada indikator kepositifan yakni sebesar 37\% atau 41 peserta didik dengan kategori rendah, peserta didik belum mampu untuk percaya pada kemampuan diri sendiri, serta tidak dapat menerima pendapat orang lain. Pada kategori sedang terdapat sebesar 56,7\% atau 63 peserta didik memiliki permasalahan peserta didik terletak pada mencakup berburuk sangka kepada orang yang baru dikenal serta tidak suka berdenkatan dengan banyak orang, serta 6,3\% atau 7 peserta didik dengan kategori tinggi telah memiliki perilaku yang percaya pada diri sendiri, serta membuat orang lain merasa berharga dengan apa yang telah diucapkannya. Berdasarkan data analisis maka dapat disimpulkan bahwa sebagian besar peserta didik cenderung memiliki kemampuan kepositifan yang rendah. Peserta didik akan diberikan layanan bimbingan pribadi sosial untuk dapat meningkatkan keterampilan kepositifan. Pemberian layanan akan difokuskan kepada satu sub indikator paling rendah berdasarkan hasil analisis kuesioner yaitu peserta didik masih belum memiliki rasa positif kepada orang lain. Layanan bimbingan pribadi sosial yang diberikan untuk meningkatkan keterampilan kepositifan kategori sedang yaitu dengan bimbingan klasikal. Materi layanan yang akan disampaikan pada bimbingan klasikal adalah pengertian rasa positif atau kepositifan, tujuan rasa positif dalam komunikasi interpersonal, serta dampak jika tidak adanya rasa positif pada komunikasi interpersonal.

Layanan bimbingan pribadi sosial yang akan diberikan pada peserta didik dengan kategori tinggi yakni bimbingan kelompok dengan metode diskusi. Metode diskusi didasarkan atas peserta didik yang telah mampu untuk menunjukkan rasa positif serta dapat berpikir positif kepada orang lain, sehingga dapat mengembangkan keterampilannya berdasarkan informasi yang didapatkannya pada saat kegiatan dikusi kelompok. Sementara itu, peserta didik dengan keterampilan kepositifan dengan kategori rendah sebanyak 41 orang akan diberikan layanan bimbingan pribadi sosial bimbingan kelompok dengan teknik permainan. Pemilihan teknik permainan diharapkan dapat meningkatkan keterampilan dukungan peserta didik dengan memanfaatkan dinamika 
yang terjalin di dalam sehingga kedepannya peserta didik dapat melakukan komunikasi interpersonal secara efektif.

\section{Indikator Kesetaraan}

Menurut Rakhmat (Pieter 2017, hlm. 74) kesetaraan merupakan sebuah cara memperlakukan orang lain secara sama dengan penuh penghargaan, tidak merasa bahwa dirinya lebih tinggi dan lebih baik dari siapapun berdasarkan rupa, status, perbedaan intelektual, kekuasaan, serta kekayaan. Kesetaraan berarti tidak membicarakan tentang perbedaan, menggurui antara satu dengan yang lain, sehingga interaksi yang terjalin dapat dilalui dengan sikap saling menghormati, menghargai, serta adanya rasa nyaman. Hasil analisis kuesioner komunikasi interpersonal pada indikator kesetaraan peserta didik kelas VII SMP Negeri2 Kota Serang menunjukkan sebanyak 4,5\% atau 5 peserta didik dengan kategori rendah dengan permasalahan yakni memandang bahwa orang lain lebih superior, dan tidak bersikap ramah kepada orang lain karena keadaan diri orang lain. Pada kategori sedang sebesar $71,1 \%$ atau 79 peserta didik memiliki kesulitan yaitu tidak ingin bergaul dengan teman yang lebih pintar dari dirinya, serta memilih teman berdasarkan kemampuan yang dimiliki orang tersebut, serta $24,4 \%$ atau 27 peserta didik dengan kategori tinggi telah mampu dapat bekerja sama dengan siapapun, serta menyadari bahwa setiap orang memiliki kelebihan dan kekurangannya masing-masing.

Keterampilan kesetaraan dengan kategori rendah hanya terdapat 5 orang yang menandakan peserta didik kelas VII SMP Negeri 2 Kota Serang sudah cukup baik pada indikator kesetaraan, tetapi masih perlu diberikan layanan agar dapat meningkatkan keterampilan kesetaraan pada peserta didik dengan kategori rendah. Layanan bimbingan pribadi sosial yang akan diberikan yakni bimbingan klasikal dengan tujuan lebih meningkatkan kesadaran akan perbedaan yang dimiliki setiap individu agar dapat menghargai sesamanya dan dapat berkomunikasi interpersonal secara efektif dapat diberikan kepaa peserta didik dengan keterampilan kesetraaan dengan kategori sedang. Selanjutnya pada peserta didik dengan keterampilan kesetaraan kategori rendah sebanyak 5 orang peserta didik akan diberikan konseling kelompok. Rendahnya keterampilan kesetaraan merupakan hal yang bersifat kuratif dikarenakan perilaku yang membedabedakan orang lain sehingga peserta didik tidak dapat berkomunikasi secara efektif dengan teman yang menurutnya berbeda. Pada peserta didik dengan keterampilan kesetaraan dengan kategori tinggi akan diberikan layanan bimbingan keompok dengan metode mindmaping. Pemilihan metode mindmaping didasarkan atas peserta didik yang telah dapat berkomunikasi tanpa membeda-bedakan orang lain, sehingga apa yang dirasakan da pernah dilakukan oleh peserta didik terhadap keterampilan kesetaraan akan dituangkan dalam sebuah mindmap untuk dapat ditempatkan di mading sekolah sehigga dapat mengedukasi peserta didik lain yang masih belum memiliki keterampilan kesetaraan yang baik. 


\section{SIMPULAN}

Penelitian yang dilakukan pada peserta didik kelas VII SMP Negeri 2 Kota Serang memiliki kesimpulan bahwa kemampuan komunikasi interpersonal peserta didik berdasarkan hasil analisis kuesioner yang diisi oleh 111 responden memperoleh data yaitu sebanyak 40 peserta didik memiliki kemampuan komunikasi interpersonal rendah dengan persentase sebesar 36,1\%, dan 53 peserta didik dengan kemampuan komunikasi interpersonal kategori sedang dengan persentase 47,7\% yang menandakan bahwa peserta didik kelas VII SMP Negeri 2 Kota Serang membutuhkan layanan khusus pada komunikasi interpersonal peserta didik. Layanan yang diberikan yaitu layanan bimbingan dan konseling pribadi sosial.

Layanan bimbingan dan konseling pribadi sosial merupakan salah satu langkah yang dapat ditempuh dalam mengatasi permasalahan komunikasi interpersonal. Sebagian besar layanan akan diberikan oleh guru bimbingan dan konseling yaitu layanan yang bersifat preventif atau pencegahan yang berisikan mengenai informasi yang bersumber dari aspek yang terdapat pada komunikasi interpersonal. Bentuk layanan yang akan diberikan yakni bimbingan kelompok dan bimbingan klasikal yang disusun dalam sebuah program bimbingan dan konseling pribadi sosial.

\section{DAFTAR PUSTAKA}

Arikunto, S. (2006). Metode Penelitian Kualitatif. Jakarta: Bumi Aksara.

Arifin, Z. (1991). Evaluasi Instruksional: Prinsip-Teknik-Prosedur. Bandung: Remaja Rosda Karya.

Asih, G. Y. \& Pratiwi, M. M. (2010). Perilaku Prososial Ditinjau dari Empati dan Kematangan Emosi. Jurnal Psikologi Universitas Muria Kudus 1(1) 33-42. Diakses dari http://eprints.umk.ac.id

Azwar, S. (1987). Sikap Manusia Teori dan Pengukurannya. Yogyakarta: Liberty.

Fatimah, D. N. (2017). Layanan Bimbingan Klasikal dalam Meningkatkan Self Control Siswa SMP Negeri 5 Yogyakarta. Jurnal Bimbingan Konseling dan Dakwah Islam 14(1) 25-37. Diakses dari http://202.0.92.5/dakwah/hisbah.

Indrawan, R. \& Yaniawati, P. (2014). Metodologi Penelitian Kuantitatif, Kualitatif, dan Campuran untuk Manajemen Pembangunan dan Pendidikan. Bandung: Refika Aditama.

Khalilah, E. (2017). Layanan Bimbingan dan Konseling Pribadi Sosial dalam Meningkatkan Keterampilan Hubungan Sosial Siswa. Journal of Islamic Guidance and Counseling 1(1) 41-57. Diakses dari http://jigc.fusa.unjambi.ac.id/index.

Maulana, M. A. et al. (2104). Model Bimbingan Kelompok Berbasis Budaya Jawa dengan Teknik Permainan untuk Meningkatkan Interaksi Sosial Siswa SMP Kota Serang. Jurnal Bimbingan Konseling 3(2) 80-96. Diakses dari http://journal.unness.ac.id/sju/index.php/jubk. 
Mulyana, D. (2016). Ilmu Komunikasi: Suatu Pengantar. Cetakan ke 18. Bandung: PT. Remaja Rosdakarya.

Narti, S. (2019). Kumpulan Contoh Laporan Hasil Penelitian Tindakan Bimbingan Konseling (PTBK). Yogyakarta: Deepublish.

Pieter, H. Z. (2017). Dasar-Dasar Komunikasi Bagi Perawat. Jakarta: Kencana.

Rakhmat, J. (2005). Psikologi Komunikasi. Bandung: PT. Remaja Rosdakarya.

Rianse, Usman dan Abdi. (2011). Metodologi Penelitian Sosial dan Ekonomi: Teori dan Aplikasi. Bandung: Alfabeta.

Soebardhy, et al. (2019). Kapita Selekta Metodologi Penelitian. Pasuruan: CV. Penerbit Qiara Media.

Sugiyono. (2016). Metode Penelitian Kuantitatif Kualitatif dan R\&D. Bandung: Alfabeta.

Suharni \& Pratama, B. D. (2016). Pemberian Layanan Bimbingan Pribadi Sosial dalam Menumbuhkan Perilaku Prososial Anak. Jurnal Ilmiah Counselia 6(2) 31-40. Diakses dari http://e-journal.unipma.ac.id.

Yusuf, A. M. (2014). Metode Penelitian Kuantitatif \& Penelitian Gabungan. Jakarta: Prenadamedia Group.

West, R. \& Turner, L. H. (2007). Introducing Communication Theory: Analysis and Aplication, 3rd ed. New York: McGraw-Hill.

Wulandari, S. et al. (2012). Upaya Meningkatkan Empati dalam Berinteraksi Sosial melalui Dinamika Kelompok Pendekatan Experiental Learning. Jurnal Indonesia Bimbingan dan Konseling: Teori dan Implikasi 1(2) 40-46. Diakses dari http://journal.unnes.ac.id/sju/index.php/jbk.

Zuhara, E. (2015). Efektivitas Teknik Sosiodrama untuk Meningkatkan Komunikasi Interpersonal Siswa. Jurnal Edukasi: Jurnal Bimbigan dan Konseling 1(1) 80-89. Diakses dari http://dx.doi.org/10.22373/je.vlil.319. 
134 | Pertiwi - Profil Komunikasi Interpersonal ... 